\title{
MENGGUGAT HEGEMONI IJMÂ'
}

\author{
Achmad Mulyadi \\ (Dosen Tetap Mata Kuliah Usul Figh pada Jurusan Syariah STAIN \\ Pamekasa, alumni S2 IAIN Sunan Kalijaga Yogyakarta)
}

\begin{abstract}
Abstrak:
Ijmâ' telah menjadi simbol dari sebuah hegemoni pemikiran pada suatu disiplin keilmuan. Ini dapat dibuktikan bahwa ijmâ' telah menjadi senjata legitimis dan ideologis untuk membela atau menumbangkan pendapat atau suatu madzhab pemikiran. Padahal, pemikiran manusia baik secara kolektif maupun individu, bukanlah merupakan suatu pemikiran yang memiliki daya supra kuat, tetapi ia selalu berada dalam wilayah dan kondisi yang berbeda. Dengan demikian, pemikiran-pemikiran seperti ijmâ' selalu berpeluang untuk didiskusikan, "qâbilun li al-niqâsy wa al-taqhyîr"
\end{abstract}

\section{Kata Kunci:}

epistemologi, hegemoni, ijmâ', bayânî, dan ijtihâd.

\section{Pendahuluan}

Apabila kita mencermati pemikiran Islâm terutama yang berorientasi pada kajian epistimologi bayânh, akan dapat ditemukan beberapa problem yang cukup melelahkan dan menghabiskan energi. Salah satu problem yang cukup kuat dan menyita energi adalah problem ijmâ' dalam disiplin ushûl al-fiqh, ilmu retorika, dan teologi khususnya. ${ }^{1}$

Problem ijmâ' ini tidak saja ditemukan pada definisi, kehujjahannya, kemungkinan terlaksananya sebuah ijmâ', cara memperoleh ijmâ' dan selainnya. Akibatnya, ijmâ' tidak hanya menjadi sebuah problem yang merasuk berbagai aspek keilmuan (pemikiran keagamaan), tetapi juga telah menjadi senjata ideologi

\footnotetext{
${ }^{1}$ Muhammad 'Abid al-Jabirî, Bunyah al-Aql al-'Arabî, Juz 2 (Beirut: Al Markâz alTsaqafî al-Adzabî,1991), hlm. 125.
} 
untuk membela atau menumbangkan pendapat ${ }^{2}$ atau suatu madzhab pemikiran. Dan yang menyedihkan adalah predikat "kafir" bagi orang yang mengingkari keputusan ijmâ'. ${ }^{3}$

Dengan demikian, betapa ijmâ' telah menjadi simbol dari sebuah hegemoni pemikiran disiplin keilmuan. Berangkat dari kenyataan ini, tulisan ini mencoba memahami persoalan yang berselingkuhan dengan ijmâ' dan mencoba membongkar hegemoni ijmâ' dalam pemikiran Islâm.

\section{Kerangka Konseptual Ijmâ'}

Secara etimologi, ijmâ' mengandung dua pengertian, yaitu: Pertama, ijmâ' berarti " kesepakatan " atau " konsensus 4 ". Pengertian seperti ini tampak seperti pernyataan al-Qur'ân "...maka tatkala mereka membawanya dan sepakat memasukkannya ke dasar sumur, ..." Kedua, ijmâ' berarti "ketetapan hati," seperti pernyataan al-Qur'ân “...maka bulatkanlah keputusanmu dan kumpullah sekutu-sekutumu..."5.

Pengertian kebahasaan di atas, tampak memunculkan sebuah perbedaan yang cukup tajam, hal ini terletak pada kuantitas orang yang mempunyai ketetapan hati, sehingga pengertian pertama sekedar "satu tekad", sedangkan yang kedua memerlukan suatu tekad kelompok. ${ }^{6}$

\footnotetext{
2 Menjadikan ijmâ' sebagai senjata ideologis berarti menafikan realitas bahwa konsep ijmâ' masih diperdebatkan. Ada yang menjadikannya sebagai hujjah dan sebagian lagi menolaknya. Namun demikian, mayoritas fuqahấ meyakininya sebagai argumen hukum tegas dan jelas, bahkan menjadikannya sebagai sumber ketiga setelah alQur'ân dan Sunnah, ijmâ' yang dimaksud adalah ijmâ' para sahabat. Namun bagaimanakah dengan ijmâ' para fuqahâ', atau para ulamâ' saat ini?.

3 Al-Jabirî, Bunyah, hlm., 127

4 Prosedur ijmâ' pada masa sahabat amat sederhana; kaum Muhâjirîn dan Anshâr berkumpul di masjid, mendiskusikan masalah yang bersangkutan, serta mengungkapkan pandangan-pandangan mereka. Pandangan yang paling logis dan masuk akal pun diterima (baik secara verbal atau diam), kemudian diterapkan oleh khalîfah. Kaidah semacam ini lalu menjadi norma yang diterima manakala tidak ada penolakan atau perselisihan terbuka. Lihat al-Hikmah, No. 11 Rabi' Tsani-Rajab 1414, hlm., 62.

5 Al-Qur'ân, Yusuf (12) : 15 dan al-Qur'ân, Yunus (10) : 71

${ }^{6}$ Pengertian seperti di atas dapat ditekusuri dalam sebuah Hadîts yang diriwayatkan oleh Mahram Ibnu Maymûn yang menyatakan bahwa Abû Bakar ketika tidak menemukan aturan yang benar dari al-Qur'ân dan Hadîts, ia memanggil para pemimpin dan orang-orang terkemuka lainnya untuk meminta nasihat dan saran
} 
Sementara itu, bila ditilik dari konteks terminilogis, konsep ijmâ' mendapatkan definisi yang cukup beragam. Al-Nazzam, seorang tokoh $\mathrm{Mu}^{\prime}$ tazilah, mendefinisikan ijmâ' sebagai setiap pendapat yang didukung oleh hujjah sekalipun pendapat itu muncul dari seseorang. ${ }^{7}$ Definisi yang ditawarkan Al-Nazzam tersebut jelas tidak sejalan dengan pengertian etimologis di atas.

Al-Ghazâlî dalam al-Mustasfâ fî Ilm al-Ushûl-nya mendefinisikan ijmâ' sebagai kesepakatan umat Muhammad tentang suatu masalah agama. ${ }^{8}$ Bila ditelusuri ungkapan al-Ghazâlî ini, jelas ia memberikan definisi yang belum jelas pula. Karena masih mengandung makna ambiguitas, maka pertanyaannya adalah ummat Muhammad yang mana? Di sini terlalu generalistis. Al-Amîdî memberikan definisi yang agak lebih khusus, di mana menurutnya ijmâ' merupakan suatu kesepakatan yang dihasilkan oleh umat Islâm, karena hanya apabila disepakati oleh seluruh umat Islâm, maka suatu pendapat yang terhindar dari kesalahan,. ${ }^{9}$ Ini pun masih menimbulkan pertanyaan, umat Islâm yang mana dan madzhab Islâm yang mana pula. Nyatanya, ulama Syî'ah mempunyai definisi ijmâ' sendiri. Menurutnya, ijmâ' adalah suatu kesepakatan yang dihasilkan oleh imam-imam mereka yang dianggap ma'shûm. ${ }^{10}$ Imâm Mâlik hanya mengakui ijmâ' apabila ijmâ' itu merupakan keputusan yang disepakati oleh penduduk Madînah. ${ }^{11}$ Dan masih banyak lagi definisi yang dikemukakan oleh para pakar hukum Islâm.

Dengan demikian, potret ijmâ' yang tidak memiliki rumusan yang jelas dan final ini, tidak saja berakibat perbedaan teori-teori, tetapi juga telah menjadi semacam senjata yang digunakan untuk

mereka. Dengan kata lain, Abû Bakar berusaha mencapai keputusan kolektif kemudian memberlakukan solusi apa yang mereka sepakati. Lihat Muhammad Abd Allâh al-Darimi, Sunan al-Darimî, (Beirut: Dâr Kutub al-Ilmiyyah, t.th.), hlm. 58. Bandingkan dengan Sayf al-Dîn al- Amîdî, Al-Ihkâm fî Ushûl al-Ahkâm (Beirut: Dâr alKutub al-Ilmiyah,1983), hlm. 10.

7 Al-Jabirî, Bunyah, hlm. 130

8 Al-Ghazâlî , al-Mustasfâ fî Ilm al-Ushûl, Juz I (Beirut: Dâr al-Kutub al-Ilmiyah, 1983) hlm., 86.

${ }^{9}$ Al-Amîdî, Al-Ihkâm, hlm. 10.

10 Al-Syawkânî, Irsyâd al-Fuhûl (Beirut: Dâr al-Fikr, t.th.), hlm. 65.

11 Wahbah al-Zuhaylî, Al-Wasith fî Ushûl al-fiqh al-Islâmî (Damaskus: Dâr alMustaqbah, 1986), hlm. 58 
membela mazhab atau pemikiran-pemikiran yang ada. Dalam kaitan ini, maka tidaklah berlebihan ketika Arkoun menyatakan bahwa ijmâ' merupakan hasil suatu proses sosial dan budaya berbagai diskusi, konflik, penataan, dan seleksi di bawah tekanan berbagai kendala ideologi, kehendak politik, dan sistem kognisi yang tidak pernah diberikan secara memadai dan menyeluruh. ${ }^{12}$ Akhirnya, keputusankeputusan problematis diambil oleh para imam dan dicatat dalam korpus suci ${ }^{13} \ldots$ atau lebih tepat disakralkan oleh waktu...dengan ungkapan-ungkapan seperti ungkapan “ ajma'a ahl al-qiblah, ajma'a alMuslimûn".

Jadi apa yang dikatakan sebagai ijmâ' dalam epistemologi bayânî, seperti dikatakan Nashr Hâmid Abû Zayd, ketika mengkritik al-Syâfi' î, bahwa "teks keagamaan" telah diajukan sumber keyakinan dan otoritas dasarnya dengan konsekuensi dari semua itu, seperti memperluas konsep teks, sehingga termasuk di dalamnya tradisitradisi, adat-istiadat, dan ljmâ'. Hal ini merupakan sikap ideologis yang bertentangan dengan sikap lain yang menjadikan akal bebas dari segala otoritas keyakinan. ${ }^{14}$ Akhirnya eksistensi ijmâ' telah menjadi semacam epistemologi dasar bagi agama. ${ }^{15} \mathrm{Hal}$ ini secara jelas dikatakan al-Ghazâlî bahwa ijmâ' menjadi dasar agama. ${ }^{16}$

\section{Ijmâ': Sebuah Problem Metodologis}

Dalam konteks pemikiran hukum Islâm, teologi, bahasa, dan ilmu-ilmu keagamaan lainnya, ijmâ' telah dijadikan sebagai sumber pemikiran dan penetapan suatu disiplin ilmu. Dalam studi

\footnotetext{
12 Muhammad Arkoun, Nalar Islam Dan Nalar Modern: Berbagai Tantangan dan Jalan Baru, terj. Rahayu S. Hidayat (Jakarta : INIS, 1994), hlm. 298.

${ }^{13}$ Ada beberapa tingkatan otoritas bagi ijmâ'. Yang paling penting adalah konsensus yang dilakukan oleh sahabat Nabî, yang oleh para fuqahâ' dianggap sebagai paling otentik. Hanya saja jumhur ulamâ' menerima konsensus dalam setiap abad dan generasi. Konsensus yang ditegakkan oleh kesepakatan eksplisit semua fuqahâ' kontemporer disebut ijmấ qawlî. Di samping itu, ijmâ' yang dianggap valid adalah ijma' sukutî, manakala para fuqahâ' mengemukakan pandangan mereka tidak menemukan oposisi verbal dari fuqaha' lainnya. Ibid, hlm. 299

14 Nasr Hamid Abu Zaid, Imam Syafi'i: Moderatisme, Eklektesisme, Arabisme, terj. Khairun Nahdiyin (Yokyakarta : LKiS, 1997), hlm. 76

15 Al-Ghazâlî , Al-Mustafâ, hlm. 176

16 Al-Anbarî, Lam'u al-Adillah fî Ushûl al-Nahwi, dikutip dalam al-Jabiri, Bunyah, hlm. 127 .
} 
kebahasaan, ijmâ' telah dijadikan sebagai dasar perundangundangan. Tanpa menggunakan ijmâ' dalam berekspresi lisan, sebuah eskpresi verbal tersebut tidak dapat dianggap sempurna atau tepat. Contoh bagaimana Ibnu Junayd menganggap tidak sah seseorang membicarakan al-Qur'ân sebagai firman Allâh dengan ucapan "Qawl Allâh". Menurut Ibnu Junayd, perkataan ini adalah tidak benar, karena menyalahi ijmâ'. Maka yang benar adalah “Kalâm Allâh". ${ }^{17}$

Apa yang digagas oleh Ibnu Junayd secara eksplisit telah menjadikan ijmâ' sebagai metode penetapan hukum kebahasaan, yang berarti bahwa sebuah kesalahan apabila kita mengatakan AlQur'ân adalah "Qawl Allâh". Jika dikaji secara kebahasaan, sebenarnya kata "Qawl" dan "Kalam" tidak memiliki perbedaan yang mendasar dan juga bukan sebuah problema. Sebab kata "Qawl" adalah bentuk mashdar dari kata "Qâla" dan kata "Kalâm" merupakan bentuk murodif dari kata "Kalam". ${ }^{18}$ Dan kalau kata "Qawl" tidak boleh dipergunakan dalam perkataan "Qawl Allâh", karena berdasarkan ijmâ', maka betapa banyak kesalahan yang terjadi dalam tulisantulisan seperti dalam kitab Hadîts maupun dalam al-Qur'ân sendiri.

Keputusan ijmâ' dalam bidang teologi adalah, misalnya, agama Islâm adalah satu-satunya agama Allâh, tidak ada agama yang dikehendaki Allâh selain Islâm. Dan Islâm menghapus atau membatalkan semua agama, dan tidak ada lagi agama yang bisa menghapuskan Islâm. ${ }^{19}$

Apabila pernyataan di atas dipandang sebagai sebuah keputusan ijmâ', mengapa hukum-hukum yang ada dalam agama Yahudi dan Kristen masih dianggap sebagai hukum, seperti kasus hukuman qishâs bagi pelaku pembunuhan sengaja yang dalam teori ushûl fiqh disebut "syar'un man qablanâ"? Memang terhadap teori ini, telah terjadi perbedaan pendapat, tetapi dalam realitasnya teori ini

17 Ibid, hlm. 126

18 Ahmad Warson Munawir, Kamus Al-Munawir, (Yogyakarta: PP. Al-Munawir, 1984), hlm. 1259.

19 al-Zuhaylî, Al-Wasith, hlm. 156 
masih diterima oleh sebagian umat Islâm ${ }^{20}$ karena hukuman tersebut ditegaskan dalam al-Qur'ân.

Pertanyaan mendasar pun dapat diajukan terhadap keputusan ijmâ' di atas. Bukankah dalam Al-Qur'ân terdapat istilah "Ahl al-Kitâb"? Menurut teori ijtihâd tradisional yang termasuk "Ahl al-Kitâb" adalah Yahudi dan Kristen. Tetapi, bila dilacak secara lebih jauh ternyata terdapat suatu riwayat, bahwa ketika Umar berada di Madânah, ia mengumpulkan beberapa sahabatnya. Umar pun melemparkan pernyataan bahwa dirinya tidak mengetahui Zoroaster itu agama, lalu ia mengajukan pertanyaan "Apakah Zoroaster itu agama ?", apakah mereka itu memiliki kitab suci, atau apakah mereka menyembah api? Mendengar pertanyaan tersebut spontan Alî bin Abî Thâlib menjawab bahwa dirinya pernah mendengar Rasûlullâh bersabda Zoroaster termasuk "Ahl al-Kitâb". ${ }^{21}$

Contoh lain tentang kuatnya hegemoni ijmâ' adalah dalam kasus takwîl seperti yang diucapkan Hasan al-Bashrî. Menurutnya apabila penduduk dimasa lalu telah menetapkan suatu takwil itu benar atau salah, maka atas ketetapan tersebut tidak boleh dilakukan ijtihâd.22 Dari beberapa contoh di atas, penulis melihat bahwa cengkraman kuku ijmâ' begitu kuat, dan tampak sekali adanya suatu kepentingan ideologis.

\section{Legitimasi Ijmâ': Sebuah Kritik Sejarah}

Proses pemunculan ijmâ' dalam pemikiran Islâm tidaklah muncul dari sebuah tataran Ilâhiyah, tetapi sesungguhnya ia merupakan suatu proses dari sebuah pertemuan ide ketika menghadapi suatu masalah yang dimana permasalahan itu membutuhkan solusi.

Memang benar argumen yuridis yang digunakan dalam menetapkan ijmâ' berbasis pada pemikiran al-Qur' ân surat al-Nisâ (4) ayat 59 dan ayat $115^{24}$ serta dan Hadîts Nabi. Kata " ulil amri " pada

${ }^{20}$ Abû Zahrah, Ushûl al-Figh (Mesir: Dâr al-Fikr, 1958), hlm. 308

21 Abdullah Saeed, "Ijtihad and innovation in neo-Modernist Islamic Thought in Indonesia" Islam and Cristion-Muslim Relation Journal, Vol. 8 No. 3 (1997)

${ }^{22}$ Al-Jabirî, Bunyah, hlm. 128.

24 Terjemahan QS. al-Nisâ: 59 adalah adalah: "Wahai orang-orang yang beriman taatilah Allah dan taatilah Rasul dan Ulil Amri diantara kamu..." Sedangkan terjemahan QS al- 
ayat tersebut, menurut pembela ijmâ', bersifat umum, yakni mencakup orang-orang yang ahli dalam disiplin agama dan ahli dalam disiplin ilmu lain seperti pemimpin negara. Tetapi Ibnu Abbâs menafsirkan kata "ulil amri" sebagai ulama, yakni mereka yang ahli dalam masalah agama. Mufassir lain memahaminya dengan pengertian "pemerintah" atau "orang-orang yang ahli dalam masalah kenegaraan (al-siyâsah)" ${ }^{25}$

Ketika mengomentari ayat yang dijadikan sandaran yuridis bagi diakuinya ijmâ' sebagai metode pengambilan keputusan hukum sebagaimana disebutkan di atas, Ibrâhim al-Nazzam (Mu'tazilah) dan al-Qasanî menyatakan bahwa dalam ayat di atas Allâh memerintahkan kepada ummatnya untuk mengembalikan keputusan itu kepada al-Qur'ân dan Hadîts, bukan kepada ummat, apabila terjadi perselisihan. Dengan demikian bagaimana mungkin kita dapat menerima ijmâ' 26 sebagai kekuatan otoritatif dalam menetapkan hukum.

Dari sini saja kita dapat melihat bahwa di kalangan ummat Islâm sendiri terjadi penafsiran yang berbeda dalam memahami teks agama. Ini berarti suatu keputusan ijmâ' menjadi sangat relatif. Selain berdasarkan ayat di atas, para pembela ijmâ' telah menjadikan sebuah Hadîts sebagai legitimasi atas kehujjatan ijmâ'. Hadîts tersebut berbunyi, "ummatku tidak akan bersepakat atas jalan kesesatan". Menurut Abd al-Wahab Khallâf, Hadîts ini menunjukkan bahwa suatu hukum yang telah disepakati oleh seluruh mujtahid merupakan hukum yang mengikat bagi ummat Islâm, yang dalam hal ini diperankan oleh seluruh mujtahid. Oleh sebab itu, sesuai dengan kandungan Hadîts di atas, maka tidaklah mungkin para mujtahid tersebut untuk melakukan

Nisâ: 115 adalah: "Barang siapa yang menentang Rosul sesudah jelas kebenaran baginya dan mengikuti jalan bukan orang mukmin,kami biarkanlah ia leluasa terhadap kesesatan yang telah dikuasainya itu dan kami masukkan ke dalam jahannam dan jahannam itu seburukburuk tempat kembali"

25 Al-Zuhaylî, al-Wasith, hlm. 96

${ }^{26}$ Konsep tentang kema'shuman ijmâ' umat telah menimbulkan berbagai masalah bagi para fuqahâ', sebab-menurut mereka- jika seseorang mempertanyakan keputusan itu, maka kema'shuman ijmâ' tersebut dipertanyakan. Dengan demikian, ketidaksetujuan seorang fâqih saja akan meruntuhkan kema'shuman yang menjamin menjadi garansi keamanan umat terhadap berbagai kesalahan dan keputusankeputusan yang salah. Lihat Al-Hikmah, No. 11 (Rabi' Tsani-Raja 1414), hlm. 70. 
kesalahan dalam menetapkan hukum. Apabila mereka telah sepakat, maka tidak ada alasan untuk menolak ijmâ' 27

Bahkan $\underline{\text { Hadîts }}$ tersebut telah dianggap sebagai alasan yang paling kuat untuk dipegangi dibanding ayat di atas, meskipun Hadîts tersebut tidak mutawatir. Al-Ghazâlî menegaskan, penetapan dalil berdasarkan Hadîts ini didasarkan pada penyandaran berbagai riwayat dengan lafadz-lafadz yang berbeda. Tetapi maknanya tetap sama, yakni menunjukkan "keishmahan ummat" dari berbuat kesalahan dan hal ini telah berlangsung di kalangan para sahabat yang tsiqah (terpercaya), yang diyakini periwayatannya dan hal ini pula masih berlangsung sampai pada masa tâbi'în dan tak seorang pun yang menolaknya. ${ }^{28}$ Jadi, jelaslah bahwa kesepakatan sahabat dan ulama telah menjadi semacam teks yang mengikat. Karena itulah, al-Ghazâlî secara tegas menyatakan bahwa suatu kesepakatan ummat berarti adanya suatu ijmâ' yang harus diikuti. ${ }^{29}$

Tetapi sejarah pemikiran Islâm mencatat bahwa Imâm Mâlik tidak mengakui adanya ijmâ' kecuali ijmâ' yang dihasilkan oleh kesepakatan yang dilakukan oleh penduduk Madînah. Karena merekalah orang-orang yang menjadi ahli waris dari Sunnah Rasûl. Tetapi ulama lain memandang bahwa ijmâ' yang diterima adalah ijmâ' sahabat, tidak mesti orang Madînah. ${ }^{30}$

Dapat diketahui bahwa ijmâ' yang tercatat dalam sejarah cukup banyak. Namun setidak-tidaknya terdapat dua format. Pertama, ijmâ' dua sahabat Abû Bakar dan Umar ketika berada di Madînah, di mana kedua sahabat ini telah menyepakati persoalan di kalangan mereka, Kedua, Islâm telah melebarkan sayap

27Hampir semua fuqahâ' klasik mengutip Hadîts tersebut guna mendukung kema'shuman umat. Satu kekecualian adalah al-Syâfi'î, kendatipun tidak menyebutkannya, ia memang meyakini bahwa umat tidak mungkin bersepakat mengenai suatu kesalahan dalam kasus ijmâ' mutlak. Lihat Abd. Wahab Khallâf, Ilm Ushûl al-Fiqh (Kuwait: Dâr al-Qalâm, 1983), hlm. 45.

${ }^{28}$ Al-Jabirî, Bunyah, hlm. 131.

${ }^{29}$ Al-Ghazâlî , Al-Mustafâ, hlm. 133.

30 Al-Jabirî, Bunyah, hlm. 133. Banyak persoalan yang dapat dijadikan contoh sebagai praktik ijmâ' pada masa-masa awal, seperti pemilihan Abû Bakar sebagai khalîfah pertama, penguburan Nabi di kamar 'Aisyah dan perang yang dilakukan oleh Abû Bakar melawan kabilah-kabilah Arab yang menolak membayar zakat. 
kekuasaannya, kemudian di kalangan Muslim telah terlahir sejumlah ahli (pemikir), sementara yang lain terpencar-pencar ke berbagai penjuru, yang tidak dapat dihitung lagi jumlahnya. Belum lagi munculnya perbedaan pendapat, arah politik, dan berbagai kepentingan lain. ${ }^{31}$

Mencermati paparan di atas, dapat dipahami bahwa penetrasi kepentingan idiologis sangat memungkinkan terjadi atau terlahirnya konsep ijmâ' dan sangat memungkinkan pula pemikiran-pemikiran madzhab sangat berperan penting dalam mengkonstruksi bangunan konsensus pemikiran ini. Apakah metode kreatif intelek ini bisa dipandang sebagai suatu keputusan kolektif? Menurut hemat penulis, keputusan ijmâ' tidak dapat dianggap sebagai kekuatan otoritatif, sebab kerangka ijmâ' seperti pada rumusan di atas bagaimana pun juga masih dalam wilayah ijtihâd. Karena sebuah ijtihâd adalah hasil dari suatu kreatifitas nalar tetap berada dalam wilayah yang bisa diperdebatkan.

\section{Ijmâ': Refleksi Pemikiran Bayânî}

Seperti telah disebutkan di atas, bahwa ijmâ' telah dijadikan sebagai salah satu sumber terpenting dalam pemikiran Islâm, yakni setelah al-Qur'ân dan Hadîts. Kerangka pemikiran ijmâ' dalam epistemologi bayân $\hat{\imath}$, didasarkan pada ketentuan teks-teks agama (alQur'ân dan Hadîts), atau khabar ahad. Hal ini diperkuat, sebagaimana dikatakan al-Jabirî, bahwa ulama Hadîts dan ahli ushûl fiqh sangat begitu kuat perhatiannya terhadap khabar ahad, hal ini didasarkan atas pertimbangan untuk merumuskan pemikiran keagamaan dan sejarah. ${ }^{32}$

Dalam menetapkan apa saja yang termasuk ke dalam kategori dan prinsip-prinsip dasar (ushîll) pemikiran Islâm dalam epistemologi bayân̂, al-Syâfi'î menyatakan; pertama, penjelasan (bayân) yang tidak membutuhkan penjelasan, ia berdiri sendiri, dalam hal ini adalah apa yang ditunjukkan Allâh kepadanya melalui nash; kedua, penjelasan yang sebagian Sunnah masih sangat diperlukan; ketiga, penjelasan yang seluruhnya bersifat global, sedangkan Sunnah muncul sebagai

\footnotetext{
31 Ibid, hlm. 132-133

32 Ibid, hlm. 123
} 
penjelasan tersendiri; keempat, penjelasan yang datang dari Sunnah dan wajib dikuti, karena Allâh memang memerintahkan untuk mentaati Rasûl-Nya, dan; kelima, penjelasan yang datang dari ijtihâd yang dihasilkan dari suatu mekanisme analogis (qiyâs) terhadap nash. ${ }^{33}$ Dari sinilah kemudian al-Syâfi'î berkesimpulan bahwa sumber pemikiran Islâm (hukum Islâm) itu terdiri atas al-Qur'ân, Hadîts dan qiyâs. Tetapi karena al-Syâfi'î menyadari bahwa qiyâs merupakan ijtihâd individual, maka ia mengedepankan ijmâ', karena ijmâ' merupakan kreasi nalar yang bersifat kolektif yang tidak akan lalai dan terjatuh ke jurang kesalahan.

Ini berarti bahwa ijmâ' dalam wacana bayânî telah menjadi sumber (ashl). Akibat lebih jauh seperti yang penulis paparkan di muka, tidak jarang seorang yang menolak ijmâ' dipandang sebagai kafir. Padahal, di kalangan ulama sendiri, dapat ditemukan sejumlah pandangan yang menyatakan bahwa ashl (dasar) pemikiran Islâm itu adalah nash dan ijtihâd.

Dari sini tampak bahwa statemen nash yang berasal dari ushûl fundamental Islâm (al-Qur'ân dan Hadîts) secara bebas dapat berarti nash keagamaan yang merupakan hasil dialog antar pemikiran yang satu dengan pemikiran yang lain, dan ini mempunyai implikasi luas dalam tradisi epistimologi Islâm.

Dengan demikian, masing-masing ulama Bayân $\hat{\imath}$ dari berbagai disiplin ilmu akan memberikan terminologi nash sesuai dengan disiplin ilmu mereka masing-masing. Sehingga tidak mengherankan ketika seorang ahli bahasa mengartikan nash sebagai nash lughâwî seperti yang dicontohkan oleh Ibnu Junayd di muka. Demikian juga dalam perspektif ulama fiqh maupun teolog. Walaupun demikian, penulis tetap mengakui pentingnya ashl dari sebuah pemikiran Islâm. Tetapi tidak berarti, bahwa keputusan ijmâ' menjadi sebuah

\footnotetext{
33 Ijmâ' yang didasarkan pada epistemologi tersebut, akan terjaga dan terjamin kema'shumannya karena diperkuat dengan dasar nash syar'î. Al-Syâfi'î menerima konsensus yang didasarkan pada nash al-Qur'ân dan Sunnah. Hanya saja, menurutnya, konsensus tidak bisa dicapai dari pendapat ijtihâdî yang tidak berbasis pada al-Qur'ân dan Sunnah. Dengan demikian, dapat juga diajukan pemikiran yang lebih logis dan bisa diterima, yaitu penggunaan ijtihâd untuk mencapai ijmâ'. Jika keputusan-keputusan semisal ini memperoleh persetujuan dari fuqahâ' lainya, selama kurun waktu tertentu, maka keputusan-keputusan itu pun dapat menjadi ijmâ'.
} 
keputusan otoritatif mutlak. Dan bagaimanapun juga, ijmâ' menurut hemat penulis tetap berada pada wilayah kreasi nalar.

Seperti diketahui pula, bahwa memang ciri khas dari pemikiran yang berpola bayân̂̀ seperti yang diinformasikan al-Jabirî adalah dialektika antara dua wujud yang berbeda, seperti ashl-furu', mu'min-kafir, dan sebagainya. Akibatnya konflik pemikiran tidak bisa terhindarkan. Padahal kita ketahui bahwa penulisan manusia (ijtihâd) selalu berada dalam lintasan waktu dan tempat. Maka sangat dimungkinkan terjadinya pergeseran, yang berarti setiap penulisan selalu terbuka untuk didiskusikan.

\section{Penutup}

Kuatnya hegemoni ijmâ' telah telah meletakkan dan menjadikan teks keagamaan sebagai sesuatu yang final, sehingga akibat lebih jauh, terperangkapnya ide-ide kreatif dan segar ke dalam sangkar taqlid dan mendekam di balik terali besi penjara tradisional. Padahal seringkali jargon Islâm itu adalah shâlihun likulli zamân wa makân didengungkan.

Pemikiran manusia, baik secara kolektif maupun individual, bukanlah merupakan suatu pemikiran yang memiliki daya supra kuat, tetapi ia selalu berada dalam wilayah dan kondisi yang berbeda. Jadi, pemikiran-pemikiran seperti ijmâ' selalu berpeluang untuk didiskusikan, atau dalam istilah Amin Abdullah "qabilun li al-niqasy wa al-taqhyir" 34

Akhirnya, apa pun bentuk pemikiran yang tertuang dalam tulisan ini, tetap berada dalam wilayah pemikiran yang terbuka untuk didiskusikan, guna menjadi bahan pemikiran bagi upaya merekonstruksi bangunan pemikiran hukum Islâm. Wallâh a'lam bi alshawâb.

\section{Daftar Pustaka}

Abdullah, M. Amin. Falsafah Kalam di Era Postmodernisme. Yogyakarta: Pustaka Pelajar, 1997.

34 M. Amin Abdullah, Falsafah Kalam di Era Postmodernisme (Yogyakarta: Pustaka Pelajar, 1997), hlm. 35. 
Amîdî, Sayf al-Dîn al-. Al-Inkâm fî̀ Ushûl all-Ahkâm. Bairut: Markâz alTsaqafî al-Arabî, 1983.

Al-Hikmah, No. 11 (Rabi' Tsani-Rajab 1414).

Amîdî, Sayf al-Dîn al-. Al-Ihkâm fî Ushûl al-Ahkâm. Beirut: Dâr al-Kutub al-Ilmiyah, 1983.

Arkoun, Muhammad. Nalar Islam Dan Nalar Modern: Berbagai Tantangan dan Jalan Baru, terj. Rahayu S. Hidayat. Jakarta : INIS, 1994.

Darimi,Muhammad Abd Allâh al-. Sunan al-Darimî. Beirut: Dâr Kutub al-Ilmiyyah, t.th.

Ghazâlî, al-. al-Mustasfâ fî Ilm al-Ushûl, Juz I. Beirut: Dâr al-Kutub alIlmiyah, 1983.

Jabirî, Muhammad 'Abid al-. Bunyah al-Aql al-'Arabî, Juz II. Beirut: Al Markâz al-Tsaqafî al-Adzabî, 1991.

Khallâf, Abd. Wahab. Ilm Ushûl al-Fiqh.Kuwait: Dâr al-Qalâm, 1983.

Munawir, Ahmad Warson, Kamus Al-Munawir, Yogyakarta: PP. AlMunawir, 1983.

Saeed,Abdullah. "Ijtihad and innovation in neo-Modernist Islamic Thought in Indonesia" Islam and Cristion-Muslim Relation Journal, Vol. 8 No. 3 (1997), hlm. 291.

Syawkânî,Al-. Irsyâd al-Fuhûl.Beirut: Dâr al-Fikr, t.th.

Zahrah, Abû. Ushûl al-Fiqh.Mesir: Dâr al-Fikr, 1958.

Zayd, Nasr Hamid Abu. Imam Syafi'i: Moderatisme, Eklektesisme, Arabisme, terj. Khairun Nahdiyin. Yokyakarta : LKiS, 1997.

Zuhaylî, Wahbah al-. Al-Wasith fî Ushûl al-figh al-Islâmî. Damaskus: Dâr al-Mustaqbah, 1986. 